\title{
Sponsored Libre Research Agreements to Create Free and Open Source Software and Hardware
}

\author{
Joshua M. Pearce ${ }^{1,2}$ (1) \\ 1 Department of Materials Science \& Engineering and Department of Electrical \& Computer Engineering, \\ Michigan Technological University, Houghton, MI 49931, USA; pearce@mtu.edu; Tel.: +1-906-487-1466 \\ 2 Department of Electronics and Nanoengineering, School of Electrical Engineering, Aalto University, \\ FI-00076 Espoo, Finland; joshua.pearce@aalto.fi
}

Received: 25 May 2018; Accepted: 4 July 2018; Published: 6 July 2018

\begin{abstract}
As a growing number of companies reject intellectual property (IP) monopoly-based business models to embrace libre product development of free and open source hardware and software, there is an urgent need to refurbish the instruments of university-corporate research partnerships. These partnerships generally use a proprietary standard research agreement (PSRA), which for historical reasons contains significant IP monopoly language and restrictions for both the company and the university. Such standard research agreements thus create an artificial barrier to innovation as both companies using a libre model and universities they wish to collaborate with must invest significantly to restructure the contracts. To solve this problem, this article provides a new Sponsored Libre Research Agreement (SLRA). The differences between the agreements are detailed. The advantages of using an SLRA are provided for any type of company and include: (1) minimizing research investments on reporting requirements; (2) reducing delays related to confidentiality and publication embargos; and (3) reducing both transaction and legal costs as well as research time losses associated with IP. Moving to libre agreements both speeds up and reduces costs for setting up collaborative research. Under the SLRA, university researchers can spend more time innovating for the same investment.
\end{abstract}

Keywords: free and open source hardware; FOSH; free and open source software; open design; open hardware; open science; open scientific hardware; OScH; P2P; P2P manufacturing; sponsored research; sponsored research agreement

\section{Introduction}

Intellectual monopoly-based business models [1-8], which rely on patents $[9,10]$ and their concomitant challenges [8,11-13], are common across both hardware and software industries. However, more recently, the software industry has embraced the concept of liberating otherwise restrictive IP using Free and Open Source Software (FOSS) [14-19]. FOSS is computer software that is available in source code form and can be used, studied, copied, modified, and redistributed either without restriction or with restrictions only to ensure that further recipients have the same rights under which it was obtained: free, or libre. Here the term "libre" will be used rather than free to convey the freedom (of access, use, and discovery) that comes with free and open source materials, not only the lack of cost (\$0). A substantial literature now exists on the benefits of FOSS over historic and more established models [14-21] and as shown in Figure 1 the concept is covered at a high rate in academia. The secret of the libre approach is that large-scale collaboration on technical problems results in superior design and innovative solutions with lower associated costs due to continuous improvement [14,22]. It is now well established that FOSS is more reliable and relevant to users [23] (in part because many FOSS users are co-developers [24]). FOSS has become so prominent in the software industry 
that it represents a significant change in the career trajectory of software developers [25] and is dominating major areas of computing. For example, Android, an open source-based operating system, is the world's most popular operating system [26], 97\% of the world's supercomputers use GNU/Linux [27], and major Internet-based corporations use and develop FOSS including: Amazon, Alphabet (Google), Twitter and Facebook. These companies and others use FOSS because of superior technical performance, more flexible design and reduced research and development (R\&D) costs [28].

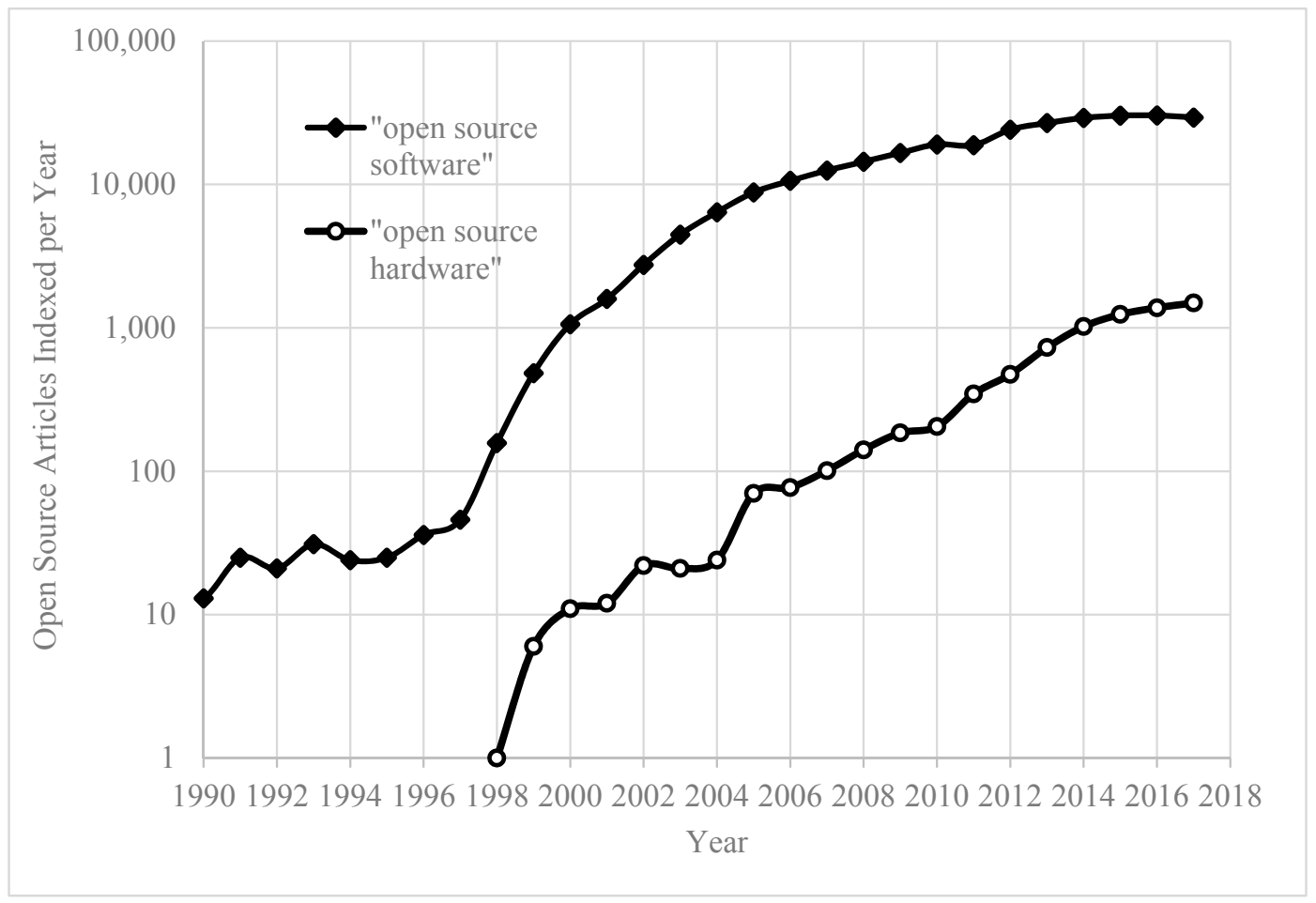

Figure 1. Articles indexed by Google Scholar containing the phrase "open source software" and "open source hardware" from 1990 until 2017 shown on a logarithmic scale because of the orders of magnitude changes.

Historically libre technical development was limited to software as the FOSS community believed that libre hardware was challenging because of the necessity of building physical objects [29]; however, within a few years these views changed with the introduction of low-cost digital distributed manufacturing tools [30] such as the self-replicating rapid protoyper (RepRap) 3-D printer family [31-34]. As FOSS has proven so successful, free and open source hardware (FOSH) gained traction in the technical communities [35]. FOSH is hardware whose design is made publicly available so that anyone can study, modify, manufacture, distribute, and sell the design or pieces of hardware based on that design [36]. FOSS/FOSH-based technical development provides a competitive advantage as innovation can include more participants than proprietary innovation within firms [14-21], it is less encumbered by IP issues [37-39], and innovation occurs at steeper rates [40]. The scientific community has been quick to adopt libre hardware as it reduces costs by 90-99\%, while improving control and allowing customizable features [41-43]. In addition to traditional publishing, new academic journals such as HardwareX (publishing libre hardware designs from potentiostat/galvanostats [44] to a microsyringe autosamplers [45]) and the Journal of Open Hardware, which covered the annual Gathering for Open Science Hardware [46] and libre hardware-based business models [47]. Some libre hardware designs have been shown to be growing at an exponential rate [41]. In addition, as shown in Figure 1, the academic community is rapidly embracing libre for both FOSS and FOSH, with the latter lagging by about 20 years based on indexing in Google Scholar. 
Companies embracing libre product development range from the multi-billion-dollar RedHat [48] to hundreds of small startup companies [35]. Most (at least 78\%) of companies now use some form of open source product [49]. Companies often partner with universities to do research following different models such as collaborative research, university-industry research centers, contract research, and sponsored research [50]. Companies generally begin their interaction with universities using a proprietary standard research agreement (PSRA), which for the historical reasons described above contains significant IP monopoly language and restrictions for both the company and the university. Such standard research agreements thus create an artificial barrier to collaboration as both companies using a libre model and universities they wish to collaborate with must invest significantly to restructure the contracts. To solve this problem, this article provides a new Sponsored Libre Research Agreement (SLRA). The differences between the PSRA and SLRA are detailed and then the advantages are discussed for using the SLRA are provided for both a fully libre company, as well as traditional companies.

\section{The Problem: Proprietary Sponsored Research Agreements}

The three primary aspects of PSRAs that limit innovation are: (1) oppressive default reporting requirements; (2) delays related to confidentiality and publication embargos; and (3) restrictive IP rules and licenses.

By definition, a researcher cannot be doing research when writing a report about the research. As academics are already heavily incentivized to document their useful results for peer-reviewed publications, any report writing is redundant and can be viewed as administrative waste [51]. This waste is increased if the reporting requirements are more frequent. PSRAs are general documents that can reflect the worst case for reporting frequency.

For both academia and industry in highly-competitive fields, research is a race and any delays are counterproductive to the goals of the research collaboration. Delays that are part of a standard PSRA involve waiting times between when confidential information is disclosed orally or visually (e.g., in a presentation of video chat) and when it is converted to a tangible form marked "confidential". Similarly, there is normally some form of embargo clause in a PSRA to ensure that the industry partner has time to read publications and presentations to ensure that no confidential information has been disclosed. These delays, which can add up to months, can represent a significant delay.

Finally, all PSRAs have language defining the use of IP, which can be complicated by which party is responsible for funding the patents, how licensing will be negotiated and reimbursed. In general, these clauses identify three types of IP: the company's IP, the university's IP and jointly developed IP. As libre companies do not use IP monopoly practices, by funding a project under a PSRA, they run the risk of enabling the production of IP on building block technologies [52-55]. This same risk exists for companies that use IP conventionally. If the project is outside of an area they target for IP protection (and even if it is joint IP development) the PSRA clause can cause unnecessary legal costs. For example, if the university creates IP the business needs or they create joint IP that the university patents, the company could have technology paths closed off or be forced to pay to license technology they funded. This is obviously counterproductive to the goals of any company.

\section{The Solution: Libre Sponsored Research Agreements}

In order to overcome the three primary deficiencies of a general PSRA, an LSRA was created for Michigan Technological University and can be found in entirety in Supplementary Material S1 in OpenDocument Text (ODT) format. Table 1 shows the core differences between a standard research agreement used at most universities and one meant to encourage libre research. 
Table 1. The core differences between a standard research agreement used at most universities and one meant to encourage libre research. Section $\mathrm{x}$ refers to the section in a specific agreement for the MTU example it is 9.2 .

\begin{tabular}{|c|c|c|}
\hline $\begin{array}{c}\text { Research Agreement } \\
\text { Section }\end{array}$ & PSRA [56] & LSRA \\
\hline $\begin{array}{l}\text { Reporting } \\
\text { Requirements }\end{array}$ & $\begin{array}{l}\text { University will provide written technical } \\
\text { progress reports as reasonably requested } \\
\text { by Sponsor but no more frequently than } \\
\text { quarterly. }\end{array}$ & $\begin{array}{l}\text { University will provide updates in } \\
\text { collaboration with the Sponsor. However, } \\
\text { written technical progress reports will be } \\
\text { provided only at the end of the project and } \\
\text { will take the form of pre-prints of articles } \\
\text { for peer-review. }\end{array}$ \\
\hline Confidentiality & $\begin{array}{l}\text { Confidential Information shall mean any } \\
\text { information disclosed by a party (the } \\
\text { Disclosing Party) to the other party (the } \\
\text { Receiving Party), and identified prior to } \\
\text { disclosure with an appropriate marking } \\
\text { or identification such as CONFIDENTIAL } \\
\text { or any other similar legend. If such } \\
\text { Confidential Information is disclosed } \\
\text { orally or visually, then the parties shall } \\
\text { use reasonable effort to reduce such oral } \\
\text { or visual Confidential Information to } \\
\text { tangible form and furnish a copy (marked } \\
\text { CONFIDENTIAL) to the Receiving Party } \\
\text { within thirty (30) days of the original oral } \\
\text { or visual disclosure. }\end{array}$ & $\begin{array}{l}\text { Confidential Information shall mean any } \\
\text { information disclosed by a party (the } \\
\text { Disclosing Party) to the other party (the } \\
\text { Receiving Party), and identified prior to } \\
\text { disclosure with an appropriate marking or } \\
\text { identification such as CONFIDENTIAL or } \\
\text { any other similar legend. As this is a Libre } \\
\text { Project Confidential Information of all kinds } \\
\text { should be minimized and as much of the } \\
\text { Project as is practical should be developed } \\
\text { openly. If such Confidential Information is } \\
\text { disclosed orally or visually, then the parties } \\
\text { shall use reasonable effort to reduce such } \\
\text { oral or visual Confidential Information to } \\
\text { tangible form and furnish a copy (marked } \\
\text { CONFIDENTIAL) to the Receiving Party } \\
\text { with the original oral or visual disclosure. }\end{array}$ \\
\hline Publication & $\begin{array}{l}\text { Except as provided in Section x, } \\
\text { University agrees not to publish or } \\
\text { otherwise disclose Confidential } \\
\text { Information. Sponsor agrees that } \\
\text { University, subject to review by Sponsor, } \\
\text { shall have the right to publish results of } \\
\text { the Project. Sponsor shall be furnished } \\
\text { copies of any proposed publication or } \\
\text { presentation at least thirty (30) days } \\
\text { before submission. Sponsor shall have } \\
\text { such thirty (30) days as a review period to } \\
\text { identify Confidential Information } \\
\text { provided by the Sponsor and to assess the } \\
\text { patentability of any invention described } \\
\text { in the proposed publication or } \\
\text { presentation. During the thirty (30) day } \\
\text { review period and upon receipt of written } \\
\text { notice from Sponsor, University shall (a) } \\
\text { remove Sponsor Confidential Information } \\
\text { identified in such notice and/or; (b) delay } \\
\text { the presentation or publication for an } \\
\text { additional ninety (90) days or until a } \\
\text { patent application is filed, whichever is } \\
\text { sooner. Should Sponsor fail to provide } \\
\text { written notice within thirty ( } 30 \text { ) days after } \\
\text { receipt of any proposed publication or } \\
\text { presentation, Sponsor shall be deemed to } \\
\text { have approved publication of the entire } \\
\text { content, and University shall be free to } \\
\text { publish or present material included in } \\
\text { the proposed publication or presentation. }\end{array}$ & $\begin{array}{l}\text { Except as provided in Section x, University } \\
\text { agrees not to publish or otherwise disclose } \\
\text { Confidential Information. Sponsor agrees } \\
\text { that University, subject to review by } \\
\text { Sponsor, shall have the right to publish } \\
\text { results of the Project. Sponsor shall be } \\
\text { furnished copies of any proposed } \\
\text { publication or presentation at least ten (10) } \\
\text { days before submission. Sponsor shall have } \\
\text { such ten (10) days as a review period to } \\
\text { identify Confidential Information provided } \\
\text { by the Sponsor. During the ten (10) day } \\
\text { review period and upon receipt of written } \\
\text { notice from Sponsor, University shall (a) } \\
\text { remove Sponsor Confidential Information } \\
\text { identified in such notice. Should Sponsor } \\
\text { fail to provide written notice within ten (10) } \\
\text { days after receipt of any proposed } \\
\text { publication or presentation, Sponsor shall } \\
\text { be deemed to have approved publication of } \\
\text { the entire content, and University shall be } \\
\text { free to publish or present material included } \\
\text { in the proposed publication or presentation. }\end{array}$ \\
\hline
\end{tabular}


Table 1. Cont.

\begin{tabular}{|c|c|c|}
\hline $\begin{array}{c}\text { Research Agreement } \\
\text { Section }\end{array}$ & PSRA [56] & LSRA \\
\hline $\begin{array}{l}\text { Intellectual Property } \\
\text { Protection }\end{array}$ & $\begin{array}{l}\text { Each party shall notify the other party of } \\
\text { any Intellectual Property disclosed to it } \\
\text { within thirty (30) days of its receipt of } \\
\text { disclosure and such disclosure shall be } \\
\text { considered Confidential Information. } \\
\text { University will, through patent counsel of } \\
\text { its choosing, prepare, file, and prosecute } \\
\text { applications for patents on any potentially } \\
\text { patentable aspects of the Intellectual } \\
\text { Property that the parties agree to pursue. } \\
\text { University will pay maintenance and } \\
\text { annuity fees on any patent applications } \\
\text { and patents the parties agree to maintain } \\
\text { in force. Sponsor will reimburse } \\
\text { University for all fees and costs associated } \\
\text { with the pursuit and maintenance of } \\
\text { patents on such potentially patentable } \\
\text { aspects of the Intellectual Property. } \\
\text { University will have ultimate } \\
\text { decision-making authority on any patent } \\
\text { applications on the Intellectual Property, } \\
\text { but will provide Sponsor with } \\
\text { information on the status of all such } \\
\text { patent applications. }\end{array}$ & $\begin{array}{l}\text { As such all Intellectual Property developed } \\
\text { by University as part of this Project will be } \\
\text { licensed under a Free and Open Source } \\
\text { Licenses and published as it is created for } \\
\text { the benefit of the Sponsor and society. Free } \\
\text { and Open Source License means a license } \\
\text { that satisfies the criteria defined by the Free } \\
\text { Software Foundation, the Open Source } \\
\text { Initiative and the Open Source Hardware } \\
\text { Association, as of the date of this } \\
\text { agreement. }\end{array}$ \\
\hline $\begin{array}{l}\text { Intellectual Property } \\
\text { Licenses }\end{array}$ & $\begin{array}{l}\text { University Intellectual Property will be } \\
\text { owned by University, and Joint } \\
\text { Intellectual Property will be owned by the } \\
\text { parties jointly. } \\
\text { University hereby grants to Sponsor a } \\
\text { non-exclusive, royalty-free license under } \\
\text { the University Intellectual Property to } \\
\text { make, use, sell, and import the University } \\
\text { Intellectual Property. Such non-exclusive } \\
\text { license is subject to termination by } \\
\text { University with respect to any patent in } \\
\text { the event Sponsor fails to reimburse } \\
\text { University for any fees and costs incurred } \\
\text { in securing and maintaining such patent. } \\
\text { Exclusive Negotiation Period shall mean } \\
\text { the six (6) month period following the } \\
\text { end-date of the Project. If Sponsor desires } \\
\text { an exclusive license under the Intellectual } \\
\text { Property, Sponsor will notify University } \\
\text { of same. In such event, University will not } \\
\text { negotiate with any third party any license } \\
\text { under the Intellectual Property during the } \\
\text { Exclusive Negotiation Period. During the } \\
\text { Exclusive Negotiation Period, the parties } \\
\text { will negotiate an exclusive license for } \\
\text { Sponsor under University's rights to the } \\
\text { Intellectual Property. Such exclusive } \\
\text { license will be subject to termination by } \\
\text { University with respect to any patent in } \\
\text { the event Sponsor fails to reimburse } \\
\text { University for any fees and costs incurred } \\
\text { in securing and maintaining such patent. } \\
\text { In the event Sponsor declines or ceases to } \\
\text { reimburse University for its costs in the } \\
\text { securing and maintaining of any patent } \\
\text { on any aspect of the Intellectual Property, } \\
\text { University may continue to secure and } \\
\text { maintain the patent at its own cost and } \\
\text { without any obligation or license to } \\
\text { Sponsor for that patent. }\end{array}$ & $\begin{array}{l}\text { University Intellectual Property will be } \\
\text { owned by University, and Joint Intellectual } \\
\text { Property will be owned by the parties } \\
\text { jointly. All Intellectual Property created as } \\
\text { part of this Project will be licensed using } \\
\text { Free and Open Source Licenses. } \\
\text { University will license all documentation } \\
\text { created as part of this project under: The } \\
\text { Creative Commons Attribution-ShareAlike } \\
4.0 \text { International Public License [57] or the } \\
\text { GNU Free Documentation License version } \\
1.3 \text { [58]. } \\
\text { University will license all software created } \\
\text { as part of this project under the GNU Free } \\
\text { Documentation License version 1.3 [58]. } \\
\text { University will license all hardware created } \\
\text { as part of this project under the CERN } \\
\text { Open Hardware License v1.2 [59]. }\end{array}$ \\
\hline
\end{tabular}




\section{Discussion}

The differences between a PSRA and SLRA shown in Table 1 are substantial. First, the reporting requirements eliminates all unnecessary reporting, which otherwise slows research progress. Second, a clause is inserted in the confidentiality section (highlighted in red in Table 1), which specifically attempts to minimize confidential information sharing and ensures that if any is shared that both parties are immediately aware of it. This reduces potential delays, which in standard PSRA contracts can be a month or more. Third, in the publication section the standard 30 days for review is shortened to 10 for journal, conference and other publications and is completely eliminated for patents (as there would not be any patents filed for inventions by either party related to the project in an SLRA). For libre projects, university and corporate partners would normally meet (even if virtually) at least weekly anyway-further delays have no benefit to either party. Rather than reducing the time to a week, 10 days accounts for someone being sick or away on a week-long vacation to ensure both parties can be compliant with the SLRA. Fourth, the intellectual property clauses have been significantly shortened as all of the inventions coming from the projects will be libre (again there will be no patents generated by the projects following and SLRA). Fifth, similarly the IP license section can be significantly reduced by detailing clear open licenses including a creative commons [57] and GFDL [58] for documentation, GFDL for FOSS and the CERN OHL [59] for FOSH. These forms of licensing not only eliminate the negotiation period, license, and reimbursements for IP related legal work from the research agreement, but also eliminate the need for the costly legal work in practice. The aggregate of the effect of moving from a PSRA to an SLRA is that both companies and universities can reduce both time and costs for setting up collaborative research by virtually eliminating legal costs. In addition, university researchers can spend more time researching and providing value to the firm for the same investment expenditures (i.e., rather than spend time on bureaucratic waste and management). In the long term, the adoption of SLRAs could even reduce the overhead associated with university research, although further work is necessary in this area to determine what that reduction would be in percent of contract funding.

It is noteworthy that in most PSRAs in the IP section there is some mention that the sponsor recognizes that the University has an obligation to utilize the knowledge and technology generated by their own research in a manner which maximize societal benefit and economic development and which provides for the education of graduate and undergraduate students. There is substantial evidence that releasing innovations and inventions using open source licenses can indeed maximizes societal benefits [5,60-62] as it leads to all of the benefits in FOSS [14-23] and FOSH [30-36,41-47] development discussed above. As the open source development of digital fabrication tools such as 3-D printers, mills and laser cutters [31-34] are coupled with software that enables convenient customization [63] and free public resources for open source design exchange [64,65], peer production can emerge [66]. These practices bring high value products to consumers for lower costs than what is available on the market for a wide range of consumer products [67-69] ranging from toys [70] and educational aids [71-75] to upper end of scientific equipment [76-78]. There is already considerable evidence that the downloaded substitution value [79] of such designs (which provide savings from 90-99\% [41,42,78,79]) can bring significant return on investments (ROIs) [80] to research funders. SLRAs could assist libre firms selling open hardware products for this market (e.g., Sparkfun, Aleph Objects, Arduino, re:3D, OpenPCR, OpenQCM, OpenTrons, Pax Instruments, etc.) accelerate their R\&D efforts with universities. In addition, there is open source development of Internet of thing (IOT)-based energy monitors for buildings [81], energy efficient homes and subsystems [82], and even smart cities [83], all of which could provide substantial ROI for government-based funders and their corporate partners working more easily with universities by using SLRAs.

However, it should also be pointed out that the same advantages can also be used in the business world following both libre and conventional IP strategies. There are a number of business models that can provide significant returns to firms using open hardware business models in this area [47] including: (1) kit, fabricated equipment, and complete tool suppliers; (2) specialty component suppliers; 
and (3) calibration and validation-related as well as using FOSH/FOSS related services. All businesses that profit by using these models would also benefit from SLRAs. Finally, even firms with conventional approaches to IP may benefit from SLRA development. For example, larger companies and those with more experience and existing patents can use a "secondary supplier model" [84] for open source sponsored research. This model works when the firm benefits from greatly expanding the size of a market (i.e., if they have a considerable market share). Then by sponsoring research at a university that would provide a new application for one of their existing products or expand the market directly by providing more users can provide high ROIs for the company. Using an SLRA speeds the process of collaboration with the university and allows more of the funds for the project to be focused on the project's goals. For example, NECi, which is primarily a bio-tech firm that manufactures enzymes, sponsored the development of an open source photometer, which radically undercut the cost of other methods to detect nitrates with the use of their enzymes [85]. By agreeing to release the designs of the tool under an open license, they encouraged new customers because their enzymes were necessary for the functioning of the device as designed. This invention effectively opened the market of lab-grade nitrate testing to the consumer and citizen scientist level, which had not been possible previously. Therefore, for example, they had established customers in the agricultural industry, but the device allowed the price point to be pushed down low enough to target small family-run farms and even gardeners.

There is considerable future work needed in this area of research agreements fostering innovation and invention. First, the benefits of the use of SLRAs should be quantified. For example, the costs for a range of businesses (both sizes and types) to run a PSRA through their legal counsel and negotiate with a range of types of universities to set up a research contract should be quantified. The research funds preserved by the aggressive time savings protections used in the SLRA could also be quantified (e.g., how many additional research hours are preserved by coupling reporting and publishing together). In addition, the impact of these time savings must be carefully evaluated as a benefit. Although time savings on bureaucratic functions may seem inherently beneficial, there is some evidence from the product development literature [86] that there is a complicated relationship between the speed of product development and quality. Whereas research time spent on the unneeded functions of the PSRA may appear wasteful, these delays could result in some unintended benefits (e.g., longer time periods to test durability). Likewise, the research investment cost per invention under a PSRA and SLRA could be compared within similar research areas in a number of fields. The same output measure could also be adopted for comparing the peer-reviewed publications output from a given amount of research expenditures operating under a PSRA and SLRA. Finally, although some companies like Red Hat may have no issues with the "no patents" stance of the SLRA discussed here, other companies may not. Future research is needed to develop a sponsored research contract that could enforce a Red Hat-like patent promise [87] or patent pledge [88]. Therefore, any inventions developed from the sponsored research which were patented would adopt a clause similar to "any patents will be accompanied with an unrestricted grant for FOSS/FOSH" development. This approach would still have some of the benefits of the libre approach to technical innovation, but would lack all of the benefits from a full SLRA.

\section{Conclusions}

This paper provided a new Sponsored Libre Research Agreement or SLRA, which overcomes many of the deficiencies of the standard proprietary research agreements between universities and companies that sponsor research. The differences between the agreements were detailed and it was concluded that the SLRA provides advantages for both fully libre companies as well as traditional companies. These advantages include: (1) minimizing research investments on reporting requirements to enable more research to take place; (2) reducing delays related to confidentiality and publication embargos; and (3) reducing both transaction and legal costs as well as research time losses associated with intellectual property protection. With the SLRA, all research is licensed with open licenses to 
ensure no IP lockdown of building block technologies, which could harm any of the parties in the agreement. The aggregate of the effect of moving from a proprietary to libre agreement is that both companies and universities can reduce economic costs for setting up collaborative research while setting them up in less time. More importantly, university researchers can spend more time researching for the same investment and thus providing more valuable inventions. Future work is needed to quantify these benefits experimentally.

Supplementary Materials: The following are available online at http:/ /www.mdpi.com/2411-5134/3/3/44/s1, Supplementary Material S1 the complete text of the SRA in OpenDocument Text (ODT) format.

Funding: This research was partially supported by Fulbright Finland.

Acknowledgments: The author would like to acknowledge helpful discussions with Marilyn Haapapuro.

Conflicts of Interest: The author declares no conflict of interest.

\section{References}

1. Demsetz, H. Industry Structure, Market Rivalry, and Public Policy. J. Law Econ. 1973, 16, 1-9. [CrossRef]

2. Amit, R.; Zott, C. Creating value through business model innovation. MIT Sloan Manag. Rev. 2012, 53, 41-49.

3. Smith, H.E. Intellectual Property as Property: Delineating Entitlements in Information. Yale Law J. 2007, 116, 1742-1822. [CrossRef]

4. May, C. The Global Political Economy of Intellectual Property Rights: The New Enclosures, 2nd ed.; Taylor \& Francis Group: Abingdon, UK, 2015.

5. Boldrin, M.; Levine, D.K. Against Intellectual Monopoly; Cambridge University Press: Cambridge, UK, 2008.

6. Boldrin, M.; Levine, DK. 2003 Lawrence R. Klein Lecture the Case Against Intellectual Monopoly. Int. Econ. Rev. 2004, 45, 327-350. [CrossRef]

7. Teece, D.J. Managing Intellectual Capital: Organizational, Strategic, and Policy Dimensions; OUP Oxford: Oxford, UK, 2000; ISBN 978-0-19-152248-2.

8. Boldrin, M.; Levine, D.K. Does Intellectual Monopoly Help Innovation? Rev. Law Econ. 2009, 5, 991-1024. [CrossRef]

9. Bagley, C.E. Winning Legally: The Value of Legal Astuteness. AMR 2008, 33, 378-390. [CrossRef]

10. WIPO—World Intellectual Property Organization. Available online: http://www.wipo.int/portal/en/index. html (accessed on 3 May 2018).

11. Rubin, R. EpiPen price hike comes under scrutiny. Lancet 2016, 388, 1266. [CrossRef] [PubMed]

12. McCarthy, M. Drug's $5000 \%$ price rise puts spotlight on soaring US drug costs. BMJ Br. Med. J. 2015, 351. [CrossRef]

13. Mcgaughey, S.L. Strategic Interventions in Intellectual Asset Flows. AMR 2002, 27, 248-274. [CrossRef]

14. Raymond, E. The cathedral and the bazaar. Knowl. Technol. Policy 1999, 12, 23-49. [CrossRef]

15. Lerner, J.; Tirole, J. Some Simple Economics of Open Source. J. Ind. Econ. 2002, 50, 197-234. [CrossRef]

16. Bonaccorsi, A.; Rossi, C. Why Open Source software can succeed. Res. Policy 2003, 32, 1243-1258. [CrossRef]

17. Lakhani, K.R.; Von Hippel, E. How open source software works: "Free” user-to-user assistance. Res. Policy 2003, 6, 923-943. [CrossRef]

18. Lakhani, K.R.; Wolf, R.G. Why Hackers Do What They Do: Understanding Motivation and Effort in Free/Open Source Software Projects; Social Science Research Network: Rochester, NY, USA, 2003.

19. Vetter, G.R. Commercial Free and Open Source Software: Knowledge Production, Hybrid Appropriability, and Patents. Fordham Law Rev. 2008, 77, 2087.

20. DiBona, C.; Ockman, S. Open Sources: Voices from the Open Source Revolution; O'Reilly Media, Inc.: Sebastopol, CA, USA, 1999; ISBN 978-0-596-55390-6.

21. Deek, F.P.; McHugh, J.A.M. Open Source: Technology and Policy; Cambridge University Press: Cambridge, UK, 2007; ISBN 978-1-139-46873-2.

22. Söderberg, J. Hacking Capitalism: The Free and Open Source Software Movement; Routledge: Abingdon, UK, 2015; ISBN 978-1-135-91639-8.

23. Kogut, B.; Metiu, A. Open source software development and distributed innovation. Oxf. Rev. Econ. Policy 2001, 17, 248-264. [CrossRef] 
24. von Hippel, E. Innovation by User Communities: Learning from Open-Source Software. MIT Sloan Manag. Rev. Camb. 2001, 42, 82-86.

25. Riehle, D. How Open Source Is Changing the Software Developer's Career. Computer 2015, 48, 51-57. [CrossRef]

26. Smith, M. Android Now the World's Most Popular Operating System. CSOnline, 2017. Available online: https:/ / www.csoonline.com/article/3187011/mobile-wireless / android-is-now-the-worlds-mostpopular-operating-system.html (accessed on 3 May 2018).

27. Vaughan-Nichols, S.J. Linux Dominates Supercomputers as Never Before I ZDNet. Available online: https: / / www.zdnet.com/article/linux-dominates-supercomputers-as-never-before/ (accessed on 3 May 2018).

28. Mockus, A.; Fielding, R.T.; Herbsleb, J.D. Two Case Studies of Open Source Software Development: Apache and Mozilla. ACM T. Softw. Eng. Methodol. 2002, 11, 309-346. [CrossRef]

29. Stallman, R.M. Richard Stallman-On "Free Hardware". LinuxToday.com, 1999. Available online: http: / / www.linuxtoday.com/news_story.php3?ltsn=1999-06-22-005-05-NW-LF (accessed on 3 May 2018).

30. Stallman, R.M. Free Hardware and Free Hardware Designs. Wired. GNU.org, 8 January 2015. Available online: http:/ / www.gnu.org/philosophy / free-hardware-designs.en.html (accessed on 3 May 2018).

31. Sells, E.; Bailard, S.; Smith, Z.; Bowyer, A.; Olliver, V. RepRap: The Replicating Rapid Prototyper-Maximizing Customizability by Breeding the Means of Production. In Handbook of Research in Mass Customization and Personalization; World Scientific: Singapore, 2009.

32. Jones, R.; Haufe, P.; Sells, E.; Iravani, P.; Olliver, V.; Palmer, C.; Bowyer, A. RepRap-the Replicating Rapid Prototyper. Robotica 2011, 29, 177-191. [CrossRef]

33. Bowyer, A. 3D Printing and Humanity's First Imperfect Replicator. 3D Print. Addit. Manuf. 2014, 1, 4-5. [CrossRef]

34. Anzalone, G.C.; Wijnen, B.; Pearce, J.M. Multi-material additive and subtractive prosumer digital fabrication with a free and open-source convertible delta RepRap 3-D printer. Rapid Prototyp. J. 2015, 21, 506-519. [CrossRef]

35. Gibb, A.; Abadie, S. Building Open Source Hardware: DIY Manufacturing for Hackers and Makers, 1st ed.; Addison-Wesley Professional: Boston, MA, USA, 2014.

36. Open Source Hardware Association. Definition (English)_Open Source Hardware Association. 2018. Available online: https:/ / www.oshwa.org/definition/ (accessed on 4 May 2018).

37. Chesbrough, H.W. Open Innovation: The New Imperative for Creating and Profiting from Technology; Harvard Business Press: Boston, MA, USA, 2006; ISBN 978-1-4221-0283-1.

38. Huizingh, E.K.R.E. Open innovation: State of the art and future perspectives. Technovation 2011, 31, 2-9. [CrossRef]

39. Yu, D.; Hang, C.C. Creating technology candidates for disruptive innovation: Generally applicable R\&D strategies. Technovation 2011, 31, 401-410. [CrossRef]

40. Foss, N.J.; Pedersen, T. Organizing knowledge processes in the multinational corporation: An introduction. J. Int. Bus. Stud. 2004, 35, 340-349. [CrossRef]

41. Pearce, J.M. Building Research Equipment with Free, Open-Source Hardware. Science 2012, 337, $1303-1304$. [CrossRef] [PubMed]

42. Pearce, J. Open-Source Lab: How to Build Your Own Hardware and Reduce Research Costs, 1st ed.; Elsevier: Waltham, MA, USA, 2014.

43. Baden, T.; Chagas, A.; Marzullo, T.; Prieto-Godino, L.; Euler, T. Open Laware: 3-D Printing Your Own Lab Equipment. PLoS Biol. 2015, 13, e1002086.

44. Dobbelaere, T.; Vereecken, P.M.; Detavernier, C. A USB-controlled potentiostat/galvanostat for thin-film battery characterization. HardwareX 2017, 2, 34-49. [CrossRef]

45. Carvalho, M.C.; Murray, R.H. Osmar, the open-source microsyringe autosampler. HardwareX 2018, 3, 10-38. [CrossRef]

46. Dosemagen, S.; Liboiron, M.; Molloy, J. Gathering for Open Science Hardware. J. Open Hardw. 2017, 1, 4. [CrossRef]

47. Pearce, J.M. Emerging Business Models for Open Source Hardware. J. Open Hardw. 2017, 1. [CrossRef]

48. RedHat. Open Source Communities Collaborate \& Innovate. Available online: https://www.redhat.com/ en/open-source (accessed on 4 May 2018). 
49. Vaughan-Nichols, S.J. It's an Open-Source World: 78 Percent of Companies Run Open-Source Software. ZDNet, 2015. Available online: https:/ / www.zdnet.com/article/its-an-open-source-world-78-percent-ofcompanies-run-open-source-software/ (accessed on 4 May 2018).

50. Markus, P.; Kathryn, W. University-industry relationships and open innovation: Towards a research agenda. Int. J. Manag. Rev. 2007, 9, 259-280. [CrossRef]

51. Pearce, J.M. Defense for Covert Administrative Techniques for Neutralizing American Highly Qualified Personnel. Am. Intell. J. 2016, 33, 126-136.

52. Lemley, M.A. Patenting Nanotechnology. Stan. Law Rev. 2005, 58, 601. [CrossRef]

53. Stiles, A.R. Hacking through the Thicket: A Proposed Patent Pooling Solution to the Nanotechnology Building Block Patent Thicket Problem. Drexel Law Rev. 2011, 4, 555.

54. Pearce, J.M. Physics: Make nanotechnology research open-source. Nature 2012, 491, 519-521. [CrossRef] [PubMed]

55. Pearce, J.M. Open-source nanotechnology: Solutions to a modern intellectual property tragedy. Nano Today 2013, 8, 339-341. [CrossRef]

56. Michigan Technological University. Agreement for Sponsored Research. 2018. Available online: http:/ /www. mtu.edu/research/administration/sponsored-programs/pdf/resagreement.pdf (accessed on 4 May 2018).

57. Creative Commons Attribution-ShareAlike 4.0 International Public License. 2018. Available online: https: / / creativecommons.org/licenses/by-sa/4.0/legalcode (accessed on 4 May 2018).

58. GNU Free Documentation License version 1.3. 2018. Available online: https://www.gnu.org/licenses/fdl-1. 3.en.html (accessed on 4 May 2018).

59. CERN Open Hardware License v1.2. 2018. Available online: https://www.ohwr.org/documents/294 (accessed on 4 May 2018).

60. Helbing, D.; Pournaras, E. Society: Build digital democracy. Nat. News 2015, 527, 33. [CrossRef] [PubMed]

61. Perkmann, M.; Schildt, H. Open data partnerships between firms and universities: The role of boundary organizations. Res. Policy 2015, 44, 1133-1143. [CrossRef]

62. McKiernan, E.C. Imagining the "open" university: Sharing scholarship to improve research and education. PLoS Biol. 2017, 15, e1002614. [CrossRef] [PubMed]

63. Nilsiam, Y.; Pearce, J.M. Free and Open Source 3-D Model Customizer for Websites to Democratize Design with OpenSCAD. Designs 2017, 1, 5. [CrossRef]

64. Coakley, M.F.; Hurt, D.E.; Weber, N.; Mtingwa, M.; Fincher, E.C.; Alekseyev, V.; Chen, D.T.; Yun, A.; Gizaw, M.; Swan, J.; et al. The NIH 3D print exchange: A public resource for bioscientific and biomedical 3D prints. 3D Print. Addit. Manuf. 2014, 1, 137-140. [CrossRef] [PubMed]

65. Moilanen, J.; Daly, A.; Lobato, R.; Allen, D. Cultures of Sharing in 3D Printing: What Can We Learn from the Licence Choices of Thingiverse Users? J. Peer Prod. 2015, 6. Available online: http:/ / peerproduction.net/issues/issue-6-disruption-and-the-law/peer-reviewed-articles/cultures-ofsharing-in-thingiverse-what-can-we-learn-from-the-licence-choices-of-thingiverse-users / (accessed on 5 July 2018).

66. Moilanen, J.; Vaden, T. 3D Printing Community and Emerging Practices of Peer Production. First Monday 2013, 18. [CrossRef]

67. Wittbrodt, B.T.; Glover, A.G.; Laureto, J.; Anzalone, G.C.; Oppliger, D.; Irwin, J.L.; Pearce, J.M. Life-cycle economic analysis of distributed manufacturing with open-source 3-D printers. Mechatronics 2013, 23, 713-726. [CrossRef]

68. Petersen, E.E.; Pearce, J. Emergence of Home Manufacturing in the Developed World: Return on Investment for Open-Source 3-D Printers. Technologies 2017, 5, 7. [CrossRef]

69. Woern, A.L.; Pearce, J.M. Distributed Manufacturing of Flexible Products: Technical Feasibility and Economic Viability. Technologies 2017, 5, 71. [CrossRef]

70. Petersen, E.E.; Kidd, R.W.; Pearce, J.M. Impact of DIY Home Manufacturing with 3D Printing on the Toy and Game Market. Technologies 2017, 5, 45. [CrossRef]

71. Kentzer, J.; Koch, B.; Thiim, M.; Jones, R.W.; Villumsen, E. An open source hardware-based mechatronics project: The replicating rapid 3-D printer. In Proceedings of the 2011 4th International Conference on Mechatronics, Kuala Lumpur, Malaysia, 7-19 May 2011; pp. 1-8.

72. Schelly, C.; Anzalone, G.; Wijnen, B.; Pearce, J.M. Open-source 3-D printing technologies for education: Bringing additive manufacturing to the classroom. J. Vis. Lang. Comput. 2015, 28, 226-237. [CrossRef] 
73. Buehler, E.; Kane, S.K.; Hurst, A. ABC and 3D: Opportunities and Obstacles to 3D Printing in Special Education Environments. In Proceedings of the 16th International ACM SIGACCESS Conference on Computers \& Accessibility (ASSETS '14), Rochester, NY, USA, 20-22 October 2014; pp. 107-114.

74. Kanev, K.; Oido, I.; Yoshioka, R.; Mirenkov, N. Employment of 3D Printing for Enhanced Kanji Learning. In Proceedings of the 2012 Joint International Conference on Human-Centered Computer Environments (HCCE '12), Aizu, Japan, 8-13 March 2012; pp. 165-170.

75. Lim, K.H.A.; Loo, Z.Y.; Goldie, S.J.; Adams, J.W.; McMenamin, P.G. Use of 3D printed models in medical education: A randomized control trial comparing 3D prints versus cadaveric materials for learning external cardiac anatomy. Anat. Sci. Educ. 2015, 9, 213-221. [CrossRef] [PubMed]

76. Zhang, C.; Wijnen, B.; Pearce, J.M. Open-source 3-D platform for low-cost scientific instrument ecosystem. J. Lab. Autom. 2016, 21, 517-525. [CrossRef] [PubMed]

77. Coakley, M.; Hurt, D.E. 3D Printing in the Laboratory: Maximize Time and Funds with Customized and Open-Source Labware. J. Lab. Autom. 2016, 21, 489-495. [CrossRef] [PubMed]

78. Pearce, J.M. Impacts of Open Source Hardware in Science and Engineering. Bridge 2017, 47, $24-31$.

79. Pearce, J. Quantifying the Value of Open Source Hardware Development. Mod. Econ. 2015, 6, 1-11. [CrossRef]

80. Pearce, J.M. Return on investment for open source scientific hardware development. Sci. Public Policy 2015, 43, 192-195. [CrossRef]

81. Pocero, L.; Amaxilatis, D.; Mylonas, G.; Chatzigiannakis, I. Open source IoT meter devices for smart and energy-efficient school buildings. HardwareX, 2017, 1, 54-67. [CrossRef]

82. Thomson, C.C.; Jakubowski, M. Toward an Open Source Civilization: (Innovations Case Narrative: Open Source Ecology). Innovations 2012, 7, 53-70. [CrossRef]

83. Jiang, J.; Claudel, C. A high performance, low power computational platform for complex sensing operations in smart cities. HardwareX 2017, 1, 22-37. [CrossRef]

84. Buitenhuis, A.J.; Pearce, J.M. Open-source development of solar photovoltaic technology. Energy Sustain. Dev. 2012, 16, 379-388. [CrossRef]

85. Wittbrodt, B.T.; Squires, D.A.; Walbeck, J.; Campbell, E.; Campbell, W.H.; Pearce, J.M. Open-Source Photometric System for Enzymatic Nitrate Quantification. PLoS ONE 2015, 10, e0134989. [CrossRef] [PubMed]

86. Lukas, B.A.; Menon, A. New product quality: Intended and unintended consequences of new product development speed. J. Bus. Res. 2005, 57, 1258-1264. [CrossRef]

87. RedHat. Patent Promise. 21 September 2017. Available online: https://www.redhat.com/en/about/patentpromise (accessed on 25 May 2018).

88. Contreras, J.L. The Evolving Patent Pledge Landscape. In University of Utah College of Law Research Paper No. 258; Social Science Research Network: Rochester, NY, USA, 2018. Available online: https:/ / papers.ssrn. com/sol3 / papers.cfm?abstract_id=3157572 (accessed on 25 May 2018). 